\title{
West Berkshire perineal management trial: three year follow up
}

\author{
JENNIFER SLEEP， ADRIAN GRANT
}

\begin{abstract}
Women who had participated in a randomised controlled trial of policies of restricted $(10 \%)$ versus liberal $(51 \%)$ episiotomy during spontaneous vaginal delivery were recontacted by postal questionnaire three years after delivery. Altogether 674 out of 1000 responded, and there was no evidence of a differential response rate between the two trial groups. Similar numbers of women in the two groups reported further deliveries, almost all of which had been vaginal and spontaneous. Fewer women allocated to restrictive use of episiotomy required perineal suturing after subsequent delivery, but this difference was not significant. Pain during sexual intercourse and incontinence of urine were equally reported in the two groups. The similarity in incontinence rates persisted when severity, type of incontinence, and subsequent deliveries were taken into account.
\end{abstract}

Liberal use of episiotomy does not seem to prevent urinary incontinence or increase long term dyspareunia.

\section{Introduction}

"Prevention of long-term damage to the pelvic floor and interference with sexual function are frequently cited reasons for episiotomy [but] there are few data to support or refute this hypothesis." With this in mind we conducted a follow up study, by means of a postal questionnaire, of women who had participated in the West Berkshire perineal management trial three years previously. ${ }^{2}$ In the original study 1000 women, who subsequently had normal vaginal deliveries at or after term, were randomly allocated to one of two policies for managing the perineum, both aimed at minimising perineal trauma. One policy, in which the midwife was encouraged

Midwifery Unit, Royal Berkshire Hospital, Reading

JENNIFER SLEEP, BA, MTD, midwifery research fellow

National Perinatal Epidemiology Unit, Radeliffe Infirmary, Oxford OX2 6HE ADRIAN GRANT, DM, MRCOG, epidemiologist

Correspondence to: Dr Grant. to try to avoid episiotomy, was associated with an episiotomy rate of $10 \%$; the other policy, in which the midwife was asked to try to prevent a tear by doing an episiotomy if necessary, resulted in an episiotomy rate of $51 \%$. The restrictive policy group had more intact perineums, had more perineal and labial tears, and included four of the five cases of more severe trauma. Despite the pronounced difference in the patterns of trauma sustained by the two groups there were no significant differences between the groups in maternal morbidity 10 days and three months after delivery other than a finding that women allocated to the restrictive policy were more likely to resume sexual intercourse within a month of delivery.

This report describes a further follow up three years after delivery with particular reference to claims that liberal use of episiotomy prevents urinary incontinence due to pelvic relaxation ${ }^{3}$ but may be associated with an increased prevalence of dyspareunia. ${ }^{4}$

\section{Patients and methods}

A standardised postal questionnaire was designed to be sent to the 1000 mothers who took part in the original study. No attempt was made to contact 15 women: eight were known to speak little English; two had refused to complete the three month questionnaire; three had given the baby for adoption; one baby had been taken into care; and one baby had died in the neonatal period. Records held by West Berkshire Family Practitioner Committee (approval for access to these records was granted by the committee registrar) showed that 481 (49\%) of the remaining 985 participants had changed their address in the three years since the original study, of whom 303 (31\%) were still living within West Berkshire Health Authority. The new address of 100 of the remaining 178 women was not known. Tracer cards bearing the National Health Service number and maiden name of these women were forwarded to the NHS central registry in Southport. These were returned bearing the code of the family practitioner committee last known to hold their records. In all 23 committees were then asked for the name of each mother's current general practitioner, to whom, subsequently, an explanatory letter was sent. The general practitioners were requested to complete the woman's address on a prestamped envelope and forward a copy of the enclosed questionnaire directly to her. We were unable to trace 63 women because they had registered in different names (one woman had changed her name six times during the three years), because they had failed to reregister for medical care in a different area, or because their h'isbands had been transferred to military posts overseas; one mother had died.

The $\chi^{2}$ test was used to compare frequencies in the two groups, and $95 \%$ confidence intervals of the relative risks were derived by the method recommended by Katz et al. ${ }^{5}$ 


\section{Results}

Six hundred and seventy four of the 1000 women who originally participated in the trial replied to the questionnaire. The response rate was high from the women who had not moved house in the intervening years (91\%) but much lower from those who had changed address (53\%). The two trial groups of respondents were well matched (table I). Their episiotomy rates $(11 \%$ and $52 \%$, respectively), patterns of perineal trauma (table I), and shorter term pain, dyspareunia, and urinary incontinence (table II) were generally closely similar to those in the total trial populations described in the original report. ${ }^{2}$ In comparison with non-responders, however, those who returned their questionnaires were older and had been delivered of heavier babies nearer term. They were more likely to have been married at the time of the index delivery, to have sustained trauma at delivery, to have reported perineal pain at the 10 day follow up, and to have resumed sexual intercourse within three months of delivery (tables I and II).

Table III shows the similarity between the respondents in the two trial groups in respect of their subsequent obstetric histories. Overall $138(42 \%)$ women in the restrictive policy group and $135(39 \%)$ in the liberal policy group had given birth since the trial. Most of these were spontaneous vaginal deliveries. The use of episiotomy and the need for perineal suturing were more common in the liberal group, but neither of these differences was significant.

Pain during sexual intercourse was reported by $52(16 \%)$ women in the restrictive group and $45(13 \%)$ in the liberal group (table IV; relative risk $=1 \cdot 21,95 \%$ confidence interval 0.84 to $1 \cdot 75, p=0.31$ ). Restricting this analysis to women who had not had any more babies made little difference to these prevalences. A total of $112(34 \%)$ women in the restrictive group and $124(36 \%)$ in the liberal group reported that they lost urine when they did not mean to (relative risk $=0.97,95 \%$ confidence interval 0.79 to $1 \cdot 19, p=0.77$ ). There was little difference between the groups in the severity of the incontinence: for $2 \%$ in each group involuntary loss of urine had occurred more than twice during the preceding week; and for $9 \%$ and $8 \%$, respectively, the incontinence was sufficiently troublesome for a pad to be worn. More specific questions about loss of urine when coughing, laughing, or sneezing or when feeling an urgent desire to pass urine but there were no facilities nearby also did not show any clear differences between the groups

TABLE I-Details of two trial groups at entry to initial trial and the perineal trauma sustained, divided into responders and non-responders to questionnaire

\begin{tabular}{|c|c|c|c|c|}
\hline & \multicolumn{2}{|c|}{ Responders } & \multicolumn{2}{|c|}{ Non-responders } \\
\hline & $\begin{array}{c}\text { Restrictive } \\
\text { policy } \\
(\mathbf{n}=329)\end{array}$ & $\begin{array}{c}\text { Liberal } \\
\text { policy } \\
(\mathbf{n}=345)\end{array}$ & $\begin{array}{c}\text { Restrictive } \\
\text { policy } \\
(\mathbf{n}=169)\end{array}$ & $\begin{array}{c}\text { Liberal } \\
\text { policy } \\
(\mathbf{n}=157)\end{array}$ \\
\hline $\begin{array}{l}\text { Mean (SD) maternal age (years) } \\
\text { No (\%) primiparous } \\
\text { No }(\%) \text { married } \\
\text { Mean (SD) gestational age of }\end{array}$ & $\begin{array}{l}27 \cdot 0(4 \cdot 9) \\
135(41) \\
300(91)\end{array}$ & $\begin{array}{l}27 \cdot 0(5 \cdot 0) \\
152(44) \\
318(92)\end{array}$ & $\begin{array}{c}25 \cdot 9(5 \cdot 6) \\
66(39) \\
145(86)\end{array}$ & $\begin{array}{l}26 \cdot 0(42) \\
67(43) \\
117(75)\end{array}$ \\
\hline $\begin{array}{l}\text { baby (weeks) } \\
\text { Mean (SD) birth weight of }\end{array}$ & $39 \cdot 8(1 \cdot 2)$ & $40 \cdot 0(1 \cdot 2)$ & $39 \cdot 7(1 \cdot 3)$ & $39 \cdot 5(1 \cdot 1)$ \\
\hline $\begin{array}{l}\text { baby }(g) \\
\text { No }(\%) \text { with posterior trauma: }\end{array}$ & $3426(430)$ & $3407(451)$ & $3330(475)$ & 3280 (394) \\
\hline $\begin{array}{l}\text { None } \\
\text { Tear alone } \\
\text { Episiotomy alone } \\
\text { Episiotomy plus extension } \\
\text { No (\%) with anterior labial tears }\end{array}$ & $\begin{array}{l}102(31) \\
190(58) \\
32(10) \\
5(2) \\
90(27)\end{array}$ & $\begin{array}{l}73(21) \\
92(27) \\
160(46) \\
20(6) \\
55(16)\end{array}$ & $\begin{array}{l}67(40) \\
88(52) \\
13(8) \\
1(1) \\
41(24)\end{array}$ & $\begin{array}{l}49(31) \\
31(20) \\
67(43) \\
10(6) \\
32(20)\end{array}$ \\
\hline
\end{tabular}

TABLE II-Morbidity at 10 days and three months post partum in two trial groups divided into responders and non-responders to questionnaire

\begin{tabular}{|c|c|c|c|c|}
\hline & \multicolumn{2}{|c|}{ Responders } & \multicolumn{2}{|c|}{ Non-responders } \\
\hline & $\begin{array}{l}\text { Restrictive } \\
\text { policy }\end{array}$ & $\begin{array}{l}\text { Liberal } \\
\text { policy }\end{array}$ & $\begin{array}{l}\text { Restrictive } \\
\text { policy }\end{array}$ & $\begin{array}{l}\text { Liberal } \\
\text { policy }\end{array}$ \\
\hline \multicolumn{5}{|c|}{10 Days after delivery } \\
\hline $\begin{array}{l}\text { No of women for whom information was } \\
\text { available } \\
\text { No }(\%) \text { with perineal pain in past } 24 \text { hours }\end{array}$ & $\begin{array}{l}295 \\
70(24)\end{array}$ & $\begin{array}{l}315 \\
77(24)\end{array}$ & $\begin{array}{l}144 \\
29(20)\end{array}$ & $\stackrel{131}{23(18)}$ \\
\hline \multicolumn{5}{|c|}{3 Months after delivery } \\
\hline $\begin{array}{l}\text { No of women for whom information was } \\
\text { available } \\
\text { No }(\%) \text { with perineal pain in past week } \\
\text { No }(\%) \text { with dyspareunia } \\
\text { No }(\%) \text { who had not attempted intercourse } \\
\text { No }(\%) \text { with urinary incontinence: }\end{array}$ & $\begin{array}{l}307 \\
18(6) \\
65(21) \\
23(7)\end{array}$ & $\begin{array}{l}338 \\
28(8) \\
57(17) \\
25(7)\end{array}$ & $\begin{array}{l}131 \\
15(11) \\
21(16) \\
16(12)\end{array}$ & $\begin{array}{c}119 \\
7(6) \\
17(14) \\
19(16)\end{array}$ \\
\hline $\begin{array}{l}\text { No pad necessary } \\
\text { Pad necessary }\end{array}$ & $\begin{array}{l}38(12) \\
19(6)\end{array}$ & $\begin{array}{l}45(13) \\
15(4)\end{array}$ & $\begin{array}{l}18(14) \\
8(6)\end{array}$ & $\begin{array}{l}14(12) \\
11(9)\end{array}$ \\
\hline
\end{tabular}

TABLE III-Deliveries in two trial groups in the three years between studies

\begin{tabular}{|c|c|c|}
\hline & $\begin{array}{c}\text { Restrictive } \\
\text { policy } \\
(\mathbf{n}=329)\end{array}$ & $\begin{array}{c}\text { Liberal } \\
\text { policy } \\
(\mathrm{n}=345)\end{array}$ \\
\hline $\begin{array}{l}\text { No of babies born since study (No (\%) of respondents): } \\
\text { None } \\
\text { One } \\
\text { Two }\end{array}$ & $\begin{array}{c}191(58) \\
131(40) \\
7(2)\end{array}$ & $\begin{array}{c}210(61) \\
130(38) \\
5(1)\end{array}$ \\
\hline $\begin{array}{l}\text { Management of first subsequent delivery }(\mathrm{No}(\%)) \text { : } \\
\text { Spontaneous vaginal } \\
\text { Instrumental } \\
\text { Caesarean section } \\
\text { No }(\%) \text { of episiotomies performed } \\
\text { No (\%) of perineums sutured } \dagger\end{array}$ & $\begin{array}{l}134(97) \\
2(1) \\
2(1) \\
21(16) \\
76(56)\end{array}$ & $\begin{array}{l}128(95) \\
4(3) \\
3(2) \\
23(19) \\
85(66)\end{array}$ \\
\hline
\end{tabular}

*For eight women in the restrictive group and 10 women in the liberal group this information was not available.

tFor one woman in the restrictive group and four women in the liberal group this information was not available.

TABLE IV-Dyspareunia and urinary incontinence reported at three years

\begin{tabular}{|c|c|c|c|c|}
\hline & \multicolumn{2}{|c|}{ All respondents } & \multicolumn{2}{|c|}{$\begin{array}{l}\text { Respondents who had had } \\
\text { no further children }\end{array}$} \\
\hline & $\begin{array}{c}\text { Restrictive } \\
\text { policy } \\
(\mathbf{n}=329)\end{array}$ & $\begin{array}{c}\text { Liberal } \\
\text { policy } \\
(\mathrm{n}=345)\end{array}$ & $\begin{array}{c}\text { Restrictive } \\
\text { policy } \\
(\mathrm{n}=191)\end{array}$ & $\begin{array}{c}\text { Liberal } \\
\text { policy } \\
(\mathrm{n}=210)\end{array}$ \\
\hline \multicolumn{5}{|l|}{ No (\%) "ever suffering painful } \\
\hline \multicolumn{5}{|l|}{ No (\%) with incontinence of urine:† } \\
\hline Less than once in past week & $69(22)$ & $82(25)$ & $44(24)$ & $54(27)$ \\
\hline Once or twice in past week & $37(12)$ & $35(11)$ & $16(9)$ & $26(13)$ \\
\hline Three or more times in past week & $6(2)$ & $7(2)$ & $5(3)$ & $5(3)$ \\
\hline \multicolumn{5}{|l|}{$\begin{array}{l}\text { No }(\%) \text { with incontinence } \\
\text { sufficiently severe to wear a pad: } t\end{array}$} \\
\hline Sometimes & $26(8)$ & $24(7)$ & $17(9)$ & $16(8)$ \\
\hline Every day & $5(2)$ & $4(1)$ & $3(2)$ & $3(1)$ \\
\hline \multirow{3}{*}{$\begin{array}{l}\text { No (\%) with loss of urine when } \\
\text { coughing, laughing, or sneezingt } \\
\text { No (\%) with loss of urine when } \\
\text { urgent desire to pass urine but no } \\
\text { toilet nearbyt }\end{array}$} & & & & \\
\hline & $103(33)$ & $105(31)$ & $56(31)$ & $73(36)$ \\
\hline & $41(13)$ & $41(13)$ & $23(13)$ & $29(15)$ \\
\hline
\end{tabular}

^For five women in each group this information was not available.

†For 19 women in the restrictive group and 12 in the liberal group this information was not available.

(table IV). Restricting these analyses to women whose most recent delivery was the one during which they were entered into the initial trial did not materially alter these findings.

The women were also asked how they felt generally; most felt very wel $(404 ; 60 \%)$, or quite well $(253 ; 38 \%)$, but a few $(12 ; 2 \%)$ did not feel well (Five women did not reply to this question.) The distribution was similar in the two trial groups.

Three of the four women allocated to the restrictive policy who had sustained more severe trauma returned completed questionnaires: al reported a minor degree of urinary incontinence, and two had dyspareunia. The one woman in the liberal group with extension of trauma to the uppe third of the vagina was normal as judged by her replies to the questionnaire.

\section{Discussion}

A frequent claim in support of liberal use of episiotomy is that it prevents pelvic relaxation and thereby urinary incontinence and genital prolapse. ${ }^{36}$ Some degree of stretching of the pelvic floor is inevitable during childbirth, but function of the pelvic floor muscles postnatally seems unrelated to perineal management at delivery, and Goodlin argued that a much more extensive incision is required if the aim really is to protect the pelvic floor.$^{8}$ Nevertheless, the different pattern of perineal trauma associated with restricted use of episiotomy, ${ }^{2}$ in particular the greater incidence of anterior vaginal and labial tears, raises the possibility that episiotomy may have a more specific protective effect on the bladder neck. The findings in an observational study of two groups of women who had contrasting perineal management but were matched on some prognostic variables are consistent with this: there were not only fewer labial tears but also fewer cystoceles in the group managed with episiotomy.'

We used the opportunity afforded by a randomised controlled 
trial of two management policies that resulted in contrasting patterns of perineal trauma to test some of these hypotheses more formally. The response rate of $67 \%$ partly reflected the high mobility of the women in the original study. Responders differed from non-responders in several respects-for example, they were more likely to be married. There was no evidence, however, of a differential response rate from women in the two trial groups, and the responders seemed comparable in the two groups with similar patterns of trauma and short term morbidity to those in the total trial population. Similar proportions of women had had more babies in the intervening three years. Women whose index deliveries had been managed with a restricted use of episiotomy seemed less likely to have episiotomies or require perineal suturing at subsequent deliveries. Both these differences are fairly likely to have been due to chance.

There was no clear difference between the groups in respect of dyspareunia. There was also no difference in the prevalence of urinary incontinence, even when the severity and nature of the incontinence, and subsequent deliveries, were taken into account.

We recognise that a more precise instrument for measuring long term morbidity associated with perineal trauma and pelvic floor relaxation might have shown differences between the two groups that our questionnaires failed to identify. Given the dispersion of the women since the original trial (questionnaires were returned from as far afield as Hong Kong, Singapore, California, Jamaica, and the Gulf States), there was no alternative to a postal questionnaire. Morbidity is difficult to measure in this way, but in the context of the trial we can see no reason why our measurements should have been biased. Most of the women had forgotten the details of the study by the time we recontacted them.
Ideally we should recontact the women in another 10 or more years to assess morbidity from genital prolapse, but given the difficulties we had in tracking down the $67 \%$ only three years after the event we are not sure how feasible such a study would be.

We thank Jo Garcia, Diana Elbourne, John Spencer, Iain Chalmers, and the many midwives and obstetricians in the West Berkshire Health District, without whose help the original trial would never have been mounted. The follow up study was made possible by Hazel Ashurst, Ann Medd, the West Berkshire Family Practitioner Committee, the staff of the NHS registry at Southport, and the women who so helpfully responded to our questionnaire. JS was funded by the Oxford Regional Health Authority. The National Perinatal Epidemiology Unit is supported by a grant from the Department of Health and Social Security.

\section{References}

1 Thacker SB, Banta HD. Benefits and risks of episiotomy: an interpretative review of the English language literature, 1860-1980. Obstet Gynecol Surv 1983;38:322-38.

2 Sleep J, Grant A, Garcia J, Elbourne D, Spencer J, Chalmers I. West Berkshire perineal management trial. Br Med J 1984;289:587-90.

Flood C. The real reason for performing episiotomies. World Medicine 1982 Feb 6: 51 .

4 Kitzinger S, Walters R. Some women's experiences of episiotomy. London: National Childbirth Trust,
$1981: 6-12$.

5 Katz D, Baptista J, Azen SP, Pike MC. Obtaining confidence intervals for the risk ratio in cohort studies. Biometrics 1978;34:469-74.

6 Willson JR. Obstetrics-gynecology: a time for a change. Am 7 Obstet Gynecol 1981;141:857-63.

7 Gordon H, Logue M. Perineal muscle function after childbirth. Lancet 1985; ii: 123-5.

8 Goodlin RC. On protection of the maternal perineum during birth. Am $\mathcal{J}$ Obstet Gynecol 1983;62:393-4.

9 Brendsel C, Peterson G, Mehl L. The role of episiotomy in pelvic symptomatology. In: Kitzinger S, ed. Episiotomy — physical and emotional aspects. London: National Childbirth Trust, 1981:36-44.

(Accepted 31 fuly 1987)

Incidence of pertussis in 90 members of 26 families in which at least one child had typical pertussis, and number from whom Bordetella pertussis was isolated. Numbers in parentheses are those members who had received two or more pertussis vaccinations

\begin{tabular}{|c|c|c|c|c|c|c|c|c|c|}
\hline \multirow[b]{3}{*}{ Pertussis } & \multicolumn{5}{|c|}{ Children } & & & & \\
\hline & \multicolumn{3}{|c|}{$<4$ years } & \multicolumn{2}{|c|}{ 4-11 years } & \multicolumn{2}{|c|}{ Parents } & \multicolumn{2}{|c|}{ Total } \\
\hline & & No & $\begin{array}{l}B \text { pertussis } \\
\text { isolated }\end{array}$ & No & $\begin{array}{l}B \text { pertussis } \\
\text { isolated }\end{array}$ & No & $\begin{array}{l}B \text { pertussis } \\
\text { isolated }\end{array}$ & No & $\begin{array}{l}\text { B pertussis } \\
\text { isolated }\end{array}$ \\
\hline $\begin{array}{l}\text { Typical } \\
\text { Atypical } \\
\text { Asymptomatic }\end{array}$ & $\ldots .$. & $33(3)$ & $14 / 30$ & $\begin{array}{r}10(1) \\
5(3)\end{array}$ & $\begin{array}{l}0 / 6 \\
0 / 3\end{array}$ & $\begin{array}{l}11 \\
12 \\
19\end{array}$ & $\begin{array}{l}2 / 10 \\
0 / 10 \\
1 / 12\end{array}$ & $\begin{array}{l}54 \\
17 \\
19\end{array}$ & $\begin{array}{l}16 / 46 \\
0 / 13 \\
1 / 12\end{array}$ \\
\hline Total & & $33(3)$ & $14 / 30$ & $15(4)$ & $0 / 9$ & 42 & $3 / 32$ & 90 & $17 / 71$ \\
\hline
\end{tabular}

\section{Patients, methods, and results}

During a large survey of serological responses to infection with Bordetella pertussis in patients with pertussis and their close contacts we recruited 26 families (42 parents and 48 children) in which we were able to obtain clinical data on all family members. The families were seen in hospital and general practice in south west London from July 1985 to January 1987 , and all of them included at least one member with typical pertussis. Families were followed up for from four to $\mathbf{4 4}$ weeks (mean 13 weeks) after presentation.
Forty three children and 11 parents had typical pertussis, defined as prolonged paroxysmal cough with whoop, vomiting, or apnoea. Five children and 12 parents had atypical pertussis, defined as brief non-paroxysmal cough without whoop, vomiting, or apnoea, which occurred within 20 days after the onset of typical symptoms of pertussis in another family member (table). Four children with typical pertussis and three children with atypical pertussis had received at least two pertussis vaccinations. Nineteen parents but no children remained asymptomatic.

In four families a parent was the first member with symptoms and presumably responsible for transmitting pertussis to the children. Of these four parents, three had typical and only one atypical pertussis. In the 22 other families the first family transmission of pertussis is disputed. Fine and Clarkson suggested that such 作 infection and atypical illness in children and adults and how commonly such infection is a source of illness for other family members. member with symptoms was a child with typical pertussis. Of the subjects exposed to pertussis by a family member, all children less than 4 years old developed typical pertussis; in contrast, five of 10 older children and 11 of 38 parents developed atypical pertussis.

$B$ pertussis was isolated from 14 of 39 children and from three of 32 parents from whom nasopharyngeal swabs were taken. The table shows the numbers of swabs that were positive on culture. Positive cultures were more common in unvaccinated children $(12 / 29)$ than in children who had been vaccinated at least once $(2 / 10)$. 